\title{
Competitive mode: Vertical control and contractual design in the poultry industry - a comparative study between Brazil and Denmark
}

\author{
Modelo competitivo: o controle vertical e o design contratual na indústria avícola - \\ um estudo comparativo entre Brasil e Dinamarca
}

\author{
Jan Ole Similä \\ Nord-Trøndelag University College.
}

\begin{abstract}
How do you see the competition in your industry? How do you see your business dealing with the actual situation? There are of course several and different answers to these questions, depending on your competitive mode. Maybe it is a choice of market strategy, cost strategy, resourcebased strategy, institutional strategy, or my choice of approach, namely a structural strategy. More precisely, I am looking at the economic organization of production, which Williamson (1991) names second-order economizing - regarding the governance structures. We are not doing the mathematics in trying to calculate efficiency, losses or benefits, as we do not have access to that kind of data. In some countries it would be possible to get hold of economic data that would make it possible to calculate possible benefits, while in other countries, companies are not required to go public with their accountings. You will find that companies deliberately tamper with their financial statements ('cook their books'), when asked about details in the economy of the production. Going along with the possibilities, what we do want to achieve is a better understanding of why different governance structures are chosen within the same industry. In this article we look at two companies engaged in large-scale industrial production, where one company is located in Brazil and the other in Denmark. The setups of the companies are completely different, where in Brazil strong vertical integration and control is emphasized, this is not equally prominent in Denmark.
\end{abstract}

Keywords: Competitive mode; Vertical control; Contractual design; Agribusiness.

Resumo: Como você vê a competição em seu setor? Como você vê o seu negócio lidar com a situação real? Há, naturalmente, várias e diferentes respostas a estas perguntas, dependendo do seu modo competitivo. Talvez seja uma escolha de estratégia de mercado, estratégia de custos, estratégia baseada em recursos, a estratégia institucional, ou a minha escolha de abordagem, ou seja, uma estratégia estrutural. Mais precisamente, eu estou olhando para a organização econômica da produção, que Williamson (1991) chama de "second-order economizing" - em relação às estruturas de governança. Nós não estamos fazendo a matemática na tentativa de calcular a eficiência, perdas ou benefícios, como não temos acesso a esse tipo de dados. Em alguns países, seria possível de se apossar de dados econômicos que tornaria possível calcular possíveis benefícios, enquanto em outros países, as empresas não são obrigadas a ir a público com suas contabilidades. Você vai descobrir que empresas deliberadamente mexem em suas demonstrações financeiras ("cook their books"), quando questionado sobre detalhes na economia da produção. Indo junto com as possibilidades, o que queremos alcançar é uma melhor compreensão de por que diferentes estruturas de governança são escolhidos dentro de um mesmo setor. Neste artigo vamos olhar para duas empresas envolvidas na produção industrial em larga escala, onde uma empresa está localizada no Brasil e outro na Dinamarca. As configurações das empresas são completamente diferentes, onde no Brasil forte integração e controle vertical é enfatizada, isso não é igualmente proeminente na Dinamarca.

Palavras-Chave: Modo competitivo; Controle Vertical; Projeto contratual; Agronegócio.

JEL: L22

\section{Introduction}

How is your organization geared in order to take on the competition? What is your competitive mode? By competitive mode, I mean the overall understanding of the situation, the degree of willingness to compete, and of course the alignment of the

Informe Gepec, Toledo, v. 18, n. 2, p. 147-162, jul./dez. 2014 
business in order to be successful. When talking to people in the poultry industry they tend to frame the overall situation as being very demanding, both in regard to public regulations and also in regard to the market situation. Public regulations have a lot to do with environmental issues and animal health issues. Regarding the market, there are a number of issues like access to supply of feed, small chicks, grown chicks, customer's expectation for instance on quality and stable delivery. From the literature we can see that product pricing, and hence production cost, is a key element for competition in the industry. Bio-security, quality, and optimization of capital resources are also important factors (HENRY and ROTHWELL 1995, MARTINEZ 2002). Further, avoiding unnecessary disruption in the production process is considered important (Gilson et al. 2009 and Martinez 2002).

Looking at different approaches to competitive strategies provided by Porter (1980), the cost leadership strategy, the differentiation strategy, and the focus strategy, it seems to be the cost leadership strategy that dominates the poultry industry. Economizing will of course be important if the company needs to work on controlling and lowering production costs. In this respect Williamson (1991) deals with three levels of economizing. First order economizing has to do with adaptation to the surrounding environment and institutions, and reducing bureaucracy and waste in the organization. Second order economizing has to do with getting the governance structures right, aligning transactions with governance structures in a transaction cost economizing way. Third order economizing has to do with getting the marginal conditions, like pricing, quantities and incentives aligned. In this paper we focus mostly on the second order economizing. We do this because there seems to be a perception, based on both the literature and dialogue with people in the business, that the standard, or benchmark, in the industry is vertical integration, or at least strong vertical control. Third order economizing might also be touched upon, depending on how you define the contracts within the vertical structure, as an outline of regular performance indicators or as incentives in a more market based structure.

The two cases we have been looking into are relatively big producers focusing mostly on frozen chickens that are not further processed. Some of the production is of course sold as fresh meat and some is processed. The Brazilian company has chosen a strong degree of vertical integration and also strong vertical control in relation to their chicken breeders. The Danish company is on the opposite end of the 'scale', no vertical integration and seemingly little vertical control. The question we want to explore in this article is how different companies in the same industry choose to approach competition in regard to their choice of their governance structure and contractual design, broadly described as the company's competitive mode. Before dealing with the cases, we will run through both transaction cost theory and agency theory, and of course also comment on state of the art within the poultry industry. Data is collected through interviews, document studies and literature review.

\section{Vertical integration in the poultry industry}

The predominant view is that vertical integration represents one extreme of an organizational continuum, ranging from vertical integration to the spot market; "inherent in the notion of vertical integration is the elimination of contractual or market exchanges" (PERRY, 1989:185). Furthermore, most agree that vertical integration means that the entity has ownership of the means of production, and thus has the power to make decisions about investment, employment, production and distribution. In reality it might be that what is described as a vertically integrated

Informe Gepec, Toledo, v. 18, n. 2, p. 147-162, jul./dez. 2014 
chain of production, combines solutions that involve ownership and contractual control - see Perry (1989) who writes that: "a firm can be described as vertically integrated if it encompasses two single-out-put production processes...” (p. 185).

On selecting governance structure Williamson (1979) suggests we have a closer look into three dimensions: Level of transaction-specific investments, transaction frequency and uncertainty. In theory the combination of high transaction frequency, transaction specific investments and uncertainty should lead to vertical integration. When transaction frequency is low, no transaction-specific investments are made and when uncertainty is low, the market solution is to be preferred.

"The poultry industry is characterized in most countries by a high level of vertical coordination ..." (HENRY and ROTHWELL 1995:1). From the North American broiler industry, we see that "Integrators usually own hatcheries, feed mills, slaughter plants, and further processing plants-that is, they may be vertically integrated into all stages except for broiler production, where they rely on networks of growers assembled through production contracts" (MAcDONALD, (2008:3). Denmark has almost the same structure as in Norway, with limited coordination between the various stages in the value chain (ANDERSEN et al. 2008). In Brazil there appears to be a large variation in the degree of vertical integration. According to Silva et al. (2005) the Brazilian poultry industry varies between vertical integration at one extreme through partnership contracts and informal agreements, to the use of the spot market at the other extreme. Parana, representing the more modern part of the industry in Brazil, where significant portions of the production are exported, seems to be dominated by partnership agreements.

The value chain in the industry includes several independent stages of production (see Figure 01).

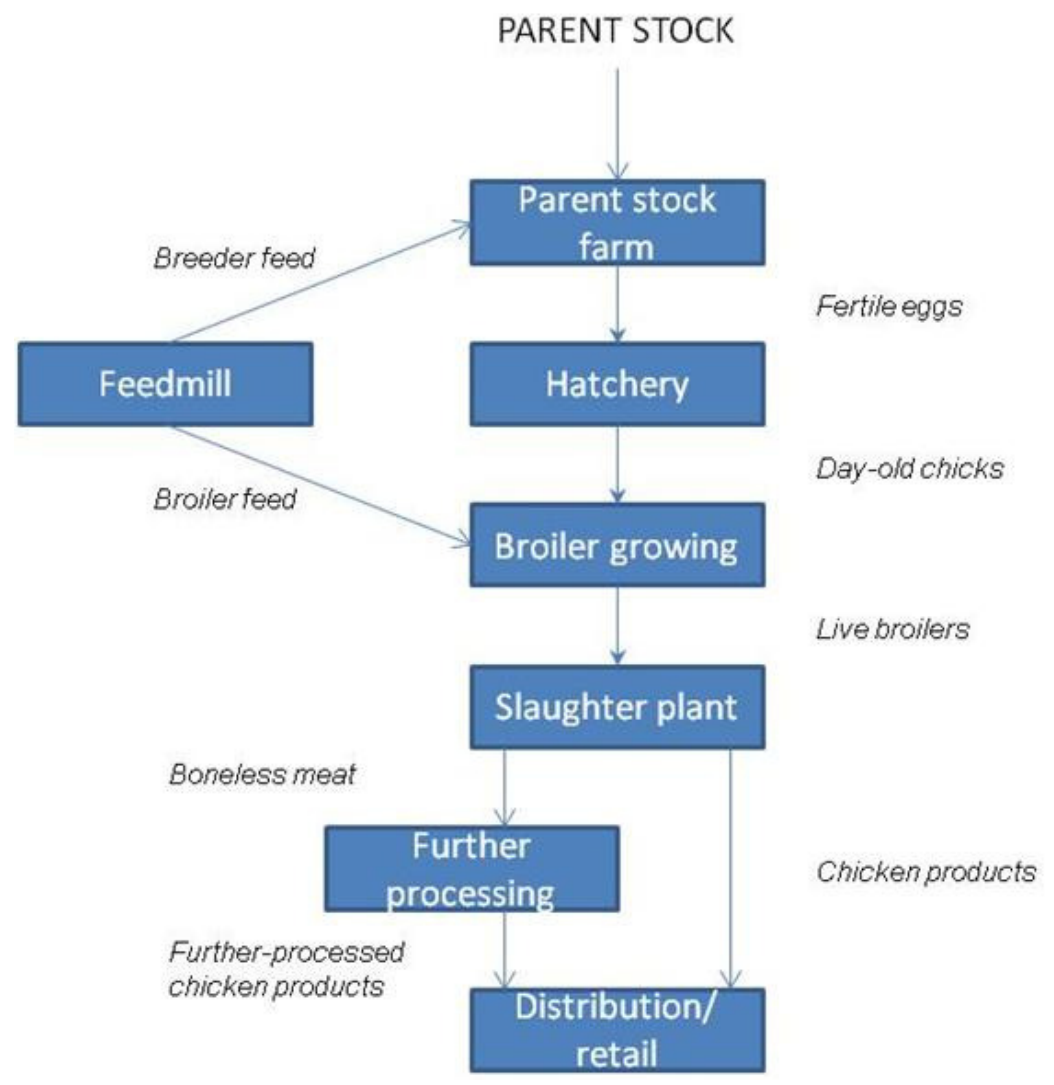

Figure 01 - Vertical integration in the poultry industry Source: Henry and Rothwell 1995:2 
Large geographical proximity between growers and slaughter plants where there are many growers and relatively few slaughter plants leads to relatively high interdependency between actors in the industry. This way of organizing the production helps to lower the costs, for instance transport costs, and thus contributes to the profitability of the industry. Large units in a geographically small area can thus be preferable.

In the literature we can see that the constructions of specialized production facilities represent a significant investment for growers. The broiler houses are expanding, and technological solutions are becoming ever more sophisticated. One challenge is that broiler houses have limited alternative applications (MAcDONALD 2008). Investment levels will probably vary depending on which climate zone production takes place, as breeding of chickens requires the 'right' balance between elements like feed, light, temperature, humidity, etc. What we can see is that livestock production in Denmark, with the cold winters is faced with challenges that Brazil would not have, as there seem to be a more ideal climate for poultry production there.

We also notice that different groups of customers have specific demands regarding quality and weight of chicken and chicken products. Product pricing is a key competitive element in the industry (cf. HENRY and ROTHWELL 1995). Altogether we have many arguments pointing in the direction of substantial control over the supply chain. Martinez (2002) makes a point of the benefits gained from increased vertical control in the broiler industry, for instance lowered production costs, compared with the costs of independent producers, technological development, better disease control, better breeds, along with the lowering of costs.

Production costs and technology as we have seen are important factors in the poultry industry. Henry and Rothwell (1995) argue that the issues surrounding the market position and margin control, biosecurity and quality, as well as economies of scale and optimization of capital resources have been forces that have affected the increased degree of vertical integration. The general impression in the food industry is that there is a focus on avoiding unnecessary disruptions in the production process, and that this is something that has helped to push forward the increased degree of vertical integration (GILSON et al. 2009 and MARTINEZ, 2002).

\section{Contracts in the poultry industry}

When you cannot regulate parameters like value and quantity of goods and services within a hierarchy, or by means of market competition, the contract is a sensible way to regulate them. The contract helps to define a social structure, in that it contributes to the coordination of bilateral relations, for instance; it is helpful regarding economic coordination, and in ensuring coordination when it comes to procedures, incentives, authority, coercion and conflict resolution. The contracts also help to provide information about how participants conceptualize policy and decision-making structures as the framework for their action (see e.g. BROUSSEAU and GLACHANT, 2002).

A normal approach to the study of contracts would be agency theory. Within this approach the key idea is that "principal-agent relationships should reflect efficient organization of information and risk-bearing costs" (EISENHARDT, 1989:59). The basic human assumption is self interest, bounded rationality and risk aversion. Furthermore, there is the assumption on partial goal conflict and information asymmetry.

Informe Gepec, Toledo, v. 18, n. 2, p. 147-162, jul./dez. 2014 
In a discussion about the length of a contract Klein et al. (1978) point to longterm contracts as the primary alternative to vertical integration where the main challenge is to seek to curb opportunism. Looking at the relationship between integrator and breeders, it seems to be relatively long-lasting and stable. MacDonald (2008) let us know that the average length of the relationship between the integrator and breeder is 13 years. The contract period may, however, vary widely, from contracts relating to individual flocks to long-term contracts up to 15 years. Breeders with the most up to date technology tend to have the longest contracts while breeders with older production facilities have contracts of shorter duration. Thus, production technology seems to be the core argument for maintaining or discontinuing a relationship.

What is interesting is that within the principal-agent tradition there seems to be an assumption that an actor's ex ante can deduce his way to an optimal contract (KNUDSEN, 1997). This is the same position that Williamson (1985) holds as he writes "The future therefore holds no surprise; all the relevant contracting action is packed into ex ante incentive alignments" (p.27). Using agency theory as an analytical approach might be challenging as it is described as comparative-static, comparing one situation with another. "What the analysis reveals, therefore, is a ranking of alternative situations, given the (efficiency) criterion employed. It will not tell you how the present situation may evolve or how to get from here to there if you are now in an inferior situation" (DOUMA and SCHREUDER, 2002:252).

From economic theory, efficiency improvements normally are explained as technical efficiency, dynamic efficiency or allocative efficiency. In poultry production all of these measures are at play. In chicken breeding the main focus is on feed conversion (technical efficiency). There is also, of course, very much focus on genetics. At the processing plant there is focus both on improvements on the slaughtering and processing part - mechanization, and to some degree on developing new products (dynamic efficiency). Overall there is a concern about the market situation (allocative efficiency). An interesting part here is what the drivers behind efficiency parameters are, market share, competition, regulations, company policies, etc. As it is "efficiency considerations are in part manifest in the assumed thoughts and behavior of economic actors" (DOUMA and SCHREUDER, 2002:249).

Contract-based solutions in the poultry industry cover the area between the spot market on one extreme and vertical integration on the other. The literature is in some ways comprehensive, as various details are discussed. In other ways the literature is limited, as there are only a few participants in the discussion and much of the literature is related to the poultry industry in United States (MARTINEZ, 2002; MAcDONALD et al. 2004; MAcDONALD, 2008; TSOULOUHAS, 1999; TSOULOUHAS and VUKINA, 1999; VUKINA, 2001; LEVY and VUKINA, 2002; WU, 2003; LEVY and VUKINA, 2004; LEEGOMONCHAI and VUKINA, 2005; VUKINA, T. and LEEGOMONCHAI, 2006; WU, 2006; ZHENG and VUKINA, 2007; VUKINA and ZHENG, 2007; DUBOIS and VUKINA, 2009; VUKINA and ZHENG, 2011).

We can see from the literature that both marketing contracts and production contracts are used. The predominant form of contracts is, according to Martinez (2002), the production contract while marketing contracts cover only a few percentages of the production. In short, through the marketing contract the breeder has control over both means of production and production decisions while the production contract is such that the integrator has substantial control over production decisions and/or means of production. Marketing contracts are performance-based, and the breeder receives payment for the results obtained, while

Informe Gepec, Toledo, v. 18, n. 2, p. 147-162, jul./dez. 2014 
production contracts at the outset are more of the behavioral kind of contracts, and the breeder receives a payment for the services rendered (MAcDONALD et al., 2004; MAcDONALD, 2008).

The key competitive elements involve the utilization of feed, reductions of the mortality of chicken, and production of kilograms of live birds (VUKINA and ZHENG, 2007). This is of course optimized through the construction of the contracts. Vukina (2001) has shown that the production contract has been under development, where the most common today are so-called tournament contracts: "Tournaments are labor contracts in which an individual's payoff depends on his or her own performance relative to that of others" (VUKINA and ZHENG, 2011:1). The layout of the contract may vary, but the point is that the contract is setup to stimulate competition among breeders to deliver the best possible results. The latest development is that contracts include a market clause in which the payment to the breeder is also dependent on market fluctuations. According Vukina (2001) the performance element of the contract constitutes between 50 and $100 \%$ of the payment to the breeder. For the breeder the performance element of beneficence will thus be a very powerful incentive.

When it comes to other aspects of research on contracts in the poultry industry, we can see that there is a focus on balancing the contracts to avoid opportunism. See e.g. Tsoulouhas (1999) which discusses the two-sided moral hazard problem, Dubois and Vukina (2009) who discuss the optimal incentive opportunity for opportunism, Leegomonchai and Vukina (2005) which discusses the dynamic incentives and the possibility of discrimination by agents. It is pointed out that opportunistic behavior can be exercised by both the principal and the agent. From the principal's point of view, opportunism can be carried on by the unequal treatment of breeders with quality and quantity of input (chicken and feed). A feature which is also considered as opportunism is that the principal fails to offer long-term contracts to individual breeders, but continues to keep them on contracts for individual flocks of chicken. From the breeder's perspective it is all about classic things to reduce their own effort (shirking), if the basic conditions are good. In addition, it is about to hold back on investments to upgrade farms. This will of course in the end represent a loss for all parties. The research shows that opportunism is not profitable while we are talking about long-term relationships. From the principal's hand, the discrimination of breeders increases transaction costs and thus they risk a loss of reputation.

Considering the research cited above, it creates an impression that tournament contracts with an extreme competitive focus are standard within the poultry industry. What has to be emphasized is that much of the research referred to has its origins in the US poultry industry.

\section{Data}

In this article we look into two cases, one in Brazil and one in Denmark. Brazil is the third largest producer of chicken, behind US and China. Denmark is part of the EU, where UK, France and Spain are the bigger producers. Both the Brazilian and the Danish companies are mass producers of chicken. Data for this study is collected through literature studies, document studies, official statistics (FAOSTAT) and interviews. 


\subsection{Lar - the Brazilian case}

Based on statistics from FAOSTAT (Food and Agriculture Organization of the United Nations), Brazil produced about 11.588.139 tons of chicken in 2012. Brazil has a steady, but slow growth in the poultry production. The average growth rate per year for the last 50 years is about $12,2 \%$ based on numbers from FAOSTAT.

The LAR Company (our case) is one of many poultry producers in Brazil. It is located in the Parana State, nearby Matelândia city, about $75 \mathrm{~km}$ from Foz do Iguacu city. One of the bigger competitors, Sadia, which is one of the brands in the Brazilian Food Company (BFR), is located in Toledo city, just $80 \mathrm{~km}$ from the LAR Company. Based on LAR's annual report for 2012 (LAR, 2012), and the annual report of the Brazilian Poultry Association, we can estimate LAR's share of the Brazilian poultry production to be slightly above $1 \%$ where about 50\% is exported. On the export market there are 31 registered Brazilian poultry producers.

Taube-Netto (1996) describes a situation where Brazil has some inherent advantages for chicken production. At the same time Nunes (2004) gives a presentation of the systematic approach to many details in developing the industry into what it is today.

The LAR Company operates as an integrator that owns most of the production process (parent birds, hatchery, feed mill, and slaughter/processing plant). The only part of the process that is contracted is the breeding of the chickens. The daily capacity at the slaughtering-/processing plant is about 300.000 chickens, so the company is in need of a big number of breeders. At the time of data collection they have contracted 450 breeders, while at the same time working to duplicate the production at several of the breeders. This is considered a better solution than searching for new breeders as there is competition among integrators to contract breeders. Economically it is also a sound solution.

Of the 450 breeding farms, 104 have ISO-certification, which is required in relation to the export market. The number of breeders with ISO-certification will be increased to about 200. The reason why all breeders will not have this certification is because there is a limited export market. The breeders that are contracted are all Brazilians located in proximity to the processing plant.

LAR provides breeders with day old chicks; actually the policy is to get the chicks out in the field within six hours. The company also provides technical assistance, medicines, supplies, transportation, food, chick collection and slaughter. Using feed or medicine from another supplier means the LAR Company will terminate the contract with the breeder, as they need to have total control of the production process.

\subsection{Danpo - the Danish case}

Based on statistics from FAOSTAT (Food and Agriculture Organization of the United Nations), Denmark produced about 177.000 tons of chicken in 2012. Denmark has a steady, but slow growth in the poultry production. Based on numbers from FAOSTAT, an average growth rate per year for the last 50 years is about 2,1\%. From the Danish Agriculture \& Food Council (www.lf.dk, 28.10.13) we find that there are two major poultry companies, Lantmännen Danpo and Rose Poultry, both producing about 200.000 chickens daily. 
Danpo is located in Aars in the northern part of Denmark. The competitor (Rose Poultry) is also located in the same part of Denmark, only $80 \mathrm{~km}$ from Aars. About $50-60 \%$ of the Danpo production is exported, mainly to EU-countries. What should be mentioned is that Danpo received the Productivity Price from Danish Industry ${ }^{1}$ for 2013 for their productivity improvements over the last years. In a press release from Danpo we can read that they have made efficiency improvements of 135 \% over the last six years. Danpo has recently become a part of Scandi Standard, owned by CapVest Equity Capital Ltd. (52 \%) and Svenska Lantmännen (48 \%). Scandi Standard is the biggest producer of chicken products within the Nordic countries.

When we look at the organization of Danish poultry production, we can see that it is not vertically integrated. The processors do have production contracts with chicken breeders. The length of the contract can vary, but breeders with new production facilities do have contracts without time limit, but with a 1 year notice of termination. The processors buy the contracted quantity of broilers. They also approve which supplier the breeders can buy day-old chicks and feed from. "Until 200o, the four private Danish poultry slaughterhouses together determined the price, but The Danish Competition Council has prohibited this practice" (OLESEN, 2002:243). The payment consists of a standard price per $\mathrm{kg}$ and bonus based on elements like quality, loyalty (contract bonus), new production facilities, no salmonella or other diseases.

The 80 breeders delivering chicken to Danpo are organized in a productionunion, Prodan, which represent the breeders in negotiations with Danpo. Breeders delivering chicken to Rose Poultry also have their own organization, LRP. The average production per breeder was 679.000 chickens in 2011 (Economics of agricultural activities 2011, Danish statistics).

\subsection{Comparative data}

\subsubsection{Governance structure}

In Figure 02 the governance structure in the Brazilian and the Danish company is displayed. As we can see, there is a great difference. Whereas LAR seems to keep strong control over their business, Danpo seems to be in less control over the chain of production.

\footnotetext{
${ }^{1}$ http://di.dk/Virksomhed/Produktion/Produktivitet/Nyheder/Pages/Envedholdendeindsatsienpressetbranche.aspx (28.10.13)
}

Informe Gepec, Toledo, v. 18, n. 2, p. 147-162, jul./dez. 2014 


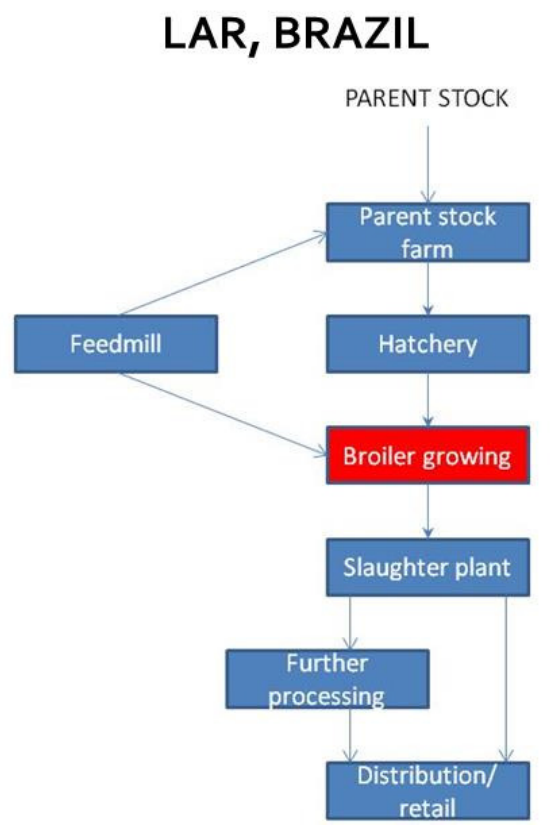

DANPO, DENMARK

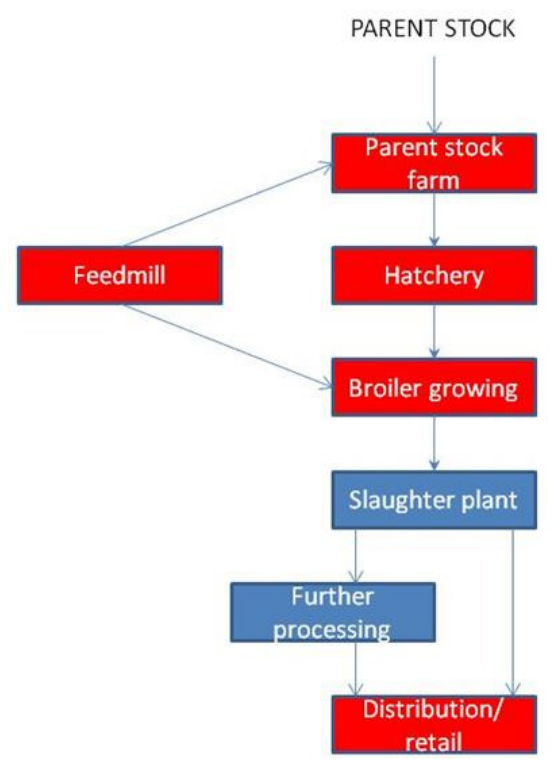

Figure 02 - Comparison of governance structure

In Table 01 we can see in more detail some of the variables that have to be included when making strategic decisions on how to organize the production.

Table 01 - Comparison of governance structure

\begin{tabular}{lccc} 
& LAR (Brazil) & Danpo (Denmark) \\
\hline $\begin{array}{l}\text { Governance structure } \\
\text { Integrated parts of the } \\
\text { value chain }\end{array}$ & $\begin{array}{c}\text { Unified governance } \\
\text { Domestic competitors on }\end{array}$ & $\begin{array}{c}\text { Market governance } \\
\text { None }\end{array}$ \\
$\begin{array}{l}\text { the export market } \\
\begin{array}{l}\text { Percentage of total } \\
\text { production }\end{array}\end{array}$ & 30 & 1 \\
$\begin{array}{l}\text { Daily production of } \\
\text { chickens }\end{array}$ & $1 \%$ & $50 \%$ \\
$\begin{array}{l}\text { Export } \\
\text { Breeders }\end{array}$ & 286.000 & 190.000 \\
Competition for breeders & $50 \%$ & $50 \%$ \\
& 400 & 80 \\
& Strong & Strong \\
\hline
\end{tabular}

What we can see is that the Brazilian company is close to the US model that we use as a benchmark, keeping strong control of the value chain in the poultry production. The Danish company is on the other end of the scale, with less direct control. One big difference between the two companies is the degree of domestic competition they are faced with. The Brazilian company only controls $1 \%$ of the total poultry production and has 30 competitors on the export market, whereas the Danish company controls about $50 \%$ of the Danish poultry production and only has one competitor on the export market. Both companies are experiencing fierce competition for good breeders. 


\subsubsection{Production contracts}

Both companies do have production contracts with the farmers breeding the chickens. The production contracts between integrator and breeders are of great importance as they deal with the single most important element that the whole industry is founded on, the chickens. The two companies, LAR and Danpo, have chosen a similar main approach as they have a somewhat collective, trust based, developmental, and helpful approach, but they never forget the controlling aspect of the contract. At the delivery date the chickens should meet an expected average weight, as this has to do with the calibration of the processing line at the slaughterhouse. The chickens should also be of expected quality.

Both companies do have the possibility to run tournament contracts but neither do so. There is no direct competition between breeders. They use different types of incentives, but the bottom line is that the breeders have to focus on heightening quality and lowering production costs to earn a decent living. The distribution of risk between integrator and breeder is different between the two cases. In the Brazilian case the integrator takes more risk than in the Danish case and the farmers take less risk in their contract with LAR than the Danish farmers do in their contract with Danpo. The details are summarized in Chart 01.

Chart 01 - Comparison of production contracts

\begin{tabular}{|c|c|c|}
\hline & LAR (Brazil) & (Danpo) Denmark \\
\hline Production contracts & $\begin{array}{c}\text { Ongoing } \\
\text { (standard contracts) }\end{array}$ & $\begin{array}{c}\text { 3-5 years } \\
\text { (standard contracts) }\end{array}$ \\
\hline - Input & $\begin{array}{l}\text { Integrator provides birds, } \\
\text { feed and medical } \\
\text { assistance }\end{array}$ & $\begin{array}{l}\text { Breeder buying birds, feed } \\
\text { and medical assistance }\end{array}$ \\
\hline $\begin{array}{ll}\text { - } & \text { Performance } \\
\text { indicator } / \mathrm{s}\end{array}$ & 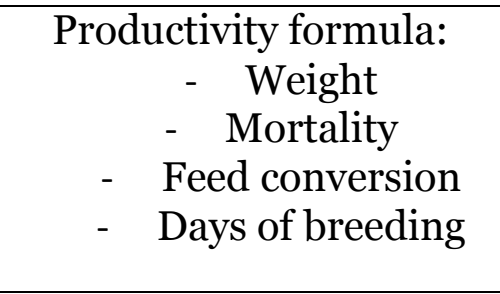 & $\begin{array}{c}\text { Number of birds } \\
\text { (at target weight) } \\
\text { Also measuring: } \\
\text { - Ammonia combustion } \\
\text { - Broken wings and legs } \\
\text { - Size of breast fillets }\end{array}$ \\
\hline - Competition & $\begin{array}{l}\text { No direct competition } \\
\text { between breeders }\end{array}$ & $\begin{array}{l}\text { No direct competition } \\
\text { between breeders }\end{array}$ \\
\hline - Dialog & $\begin{array}{l}\text { With breeders and } \\
\text { breeders 'association' }\end{array}$ & $\begin{array}{l}\text { With breeders and } \\
\text { breeders association }\end{array}$ \\
\hline - Risk - integrator & All input & $\begin{array}{l}\text { Guaranteed price and } \\
\text { profit }\end{array}$ \\
\hline - Risk - breeder & Breeding facility & $\begin{array}{l}\text { All input and breeding } \\
\text { facility }\end{array}$ \\
\hline $\begin{array}{l}\text { - General contractual } \\
\text { approach/relation }\end{array}$ & $\begin{array}{l}\text { Collective, trust based, } \\
\text { developmental, helpful, } \\
\text { but also controlling }\end{array}$ & $\begin{array}{l}\text { Collective, trust based, } \\
\text { developmental, helpful, } \\
\text { but also controlling }\end{array}$ \\
\hline
\end{tabular}




\subsubsection{Choice of governance structure}

The benchmark for choice of governance structure in the poultry industry is vertical integration. Then we are supposed to eliminate what Perry (1989:185) calls "contractual or market exchanges". The Brazilian case is very close to this 'extreme' definition of vertical integration, but still a vital part of the value chain is left outside the hierarchy. Here, the argument made by Klein et al. (1978) can be helpful, as they claim that long-term contracts are an alternative to vertical integration if the main challenge is to deal with opportunism. As we can see from the data, the production contracts are ongoing. The Brazilian case seems to be captured by what Robertson \& Langlois (1995) term the property-right view of economic organization. The Danish case does not fall under the definition of a vertically integrated firm, not even the weaker position Perry (1989) describes where "a firm can be described as vertically integrated if it encompasses two single-out-put production processes." (p. 185). Even the argument of the long term contract, provided by Klein et al (1978) is of help in defining the Danish poultry production as vertically integrated. Using Robertson \& Langlois (1995) the Danish case seems to be closer to the nexus of contract view of the firm. This means the company will miss some of the important advantages a hierarchical structure has, as Williamson (1971) explains it, e.g. constitutional authority.

The implicit arguments for establishing a vertically integrated firm in Brazil are of course the need to be in control of the quality of end product reaching the market, and also being able to compete on the world market. Being vulnerable to opportunistic behavior does not seem to be an option. The Danish case is more complicated to understand when using transaction cost theory. The 'normal' solutions should be vertical integration, not the more market-like solution that we can see. In many ways you have to understand and accept the Danish tradition regarding division of labor within the agriculture business. Even if it, from the outset, seems to be a very market-based approach to the production, traditions and interdependence keeps the structure together. This is, though, beyond the rationality of transaction cost theory.

\subsubsection{The production contracts}

There are several things of interest regarding the production contracts. Both in Brazil and Denmark there is a strong competition between integrators to contract chicken breeders. At the same time we can observe that both LAR and Danpo use standardized contracts. A normal approach would be that entering a contract is voluntary, and if there is competition for your services, you have a possibility to negotiate on the contractual terms. This is not happening, at least not on an individual basis. Breeders accept the standard contract. This might of course be a decision based on transaction cost assessments from both sides (an estimation of negotiation power) but it can also be based on the collective mindset we find within agribusiness; dialogue between the integrator and breeders' association. Another point of interest is the length of the contracts. LAR provides ongoing contracts, which can generate an impression of a vertically integrated system (KLEIN et al. 1978). The Danpo approach with time limited and also relatively short contracts back up the

Informe Gepec, Toledo, v. 18, n. 2, p. 147-162, jul./dez. 2014 
impression of a system that is not integrated, but more market based. Then, there is the combination of variables in relation to incentives, risk and control. As integrator LAR takes a lot of risk, as they are responsible for all input used by the breeders. They also take a huge responsibility in the breeding process, following up on and controlling the breeders. This makes it all seem more like a behavioral contract (EISENHARDT, 1989). The incentive, based on the performance indicators, is tipping the contract in a result based direction. All in all this represents a combination of behavioral based and result based contracting. The Danpo contract leaves more of the risk on the breeders, as they are responsible for all input. The breeders are supposed to deliver the right amount of chickens at target weight at the right time, which will classify as a result based contract (EISENHARDT, 1989). What Danpo has done is to implement an automatic control system that will help them evaluate the quality of the chickens they receive. The system also, indirectly, can be used to feedback information to breeders on the quality of the breeding facilities.

Everything about the production contract provided by LAR, points to the direction of a vertically integrated system in which the integrator is in control of the whole process. The Danpo contract strengthens the impression of a market based production.

\subsection{Discussion}

What we experience both from the empirical and theoretical analysis is that two large integrators in the poultry industry, which are exposed to international competition have chosen very different ways of setting up their business. The Brazilian company has the property-right view of economic organization while the Danish company uses the nexus of contract approach. In the Brazilian company there is a high degree of both ownership integration and coordination integration. As Robertson and Langlois (1995) explain, ownership does not, by itself, lead to centralized control, but in the Brazilian case it seems that there is a lot of control through-out the value chain, as it is very important to control animal health, security of supply, and the ability to conduct long-term investment. By this way of organizing the production LAR has access to coordination mechanisms described by Williamson (1971). The Danish company relies heavily on the market mechanisms as they choose to coordinate much of their activity on relatively open-ended contracts, although there is a dialogue between the company and suppliers of input to the chicken breeders. Perhaps a good dialogue is as good as detailed contracts when it comes to coordinating business, especially where the market for the suppliers is very limited hence leading to great interdependence. As the Danish market also is a smaller market than the Brazilian market, and thereby more transparent, it might be helpful to curb potential opportunism from any of the actors.

The question that can be raised is whether there really is a best solution. The governance structure of the Brazilian company is close to the benchmark we have chosen, while the Danish company is seemingly having a very different setup. If we use transaction cost as our main argument, Langlois (1997) argues that in the long run transaction costs (and governance costs in general) might be expected to approach zero, as activities have become increasingly routine. Perhaps the Danish agro industry is more routinized than the Brazilian.

If we look at the production contracts, our benchmark contract is a so called 'two-part cardinal-tournament scheme'. Danpo is running something close to a

Informe Gepec, Toledo, v. 18, n. 2, p. 147-162, jul./dez. 2014 
'guaranteed-price contract', while LAR is running a 'basic feed-conversion contract'. According to Vukina (2001), the guaranteed-price contracts were popular in the 1950's and 1960's, as a second generation of production contracts in the poultry industry. The feed-conversion contract is a third-fourth generation contract, a development of what is called a flat-fee contract. Both LAR and Danpo seem to be doing ok with their type of contracts, which both are, in my point of view, very different from the tournament contracts described as our benchmark.

It is appropriate to ask if the tournament contracts are better, and if the Brazilian and Danish companies are lagging behind. Research comparing tournaments with fixed performance standards in regard to behavioral and welfare effects are not conclusive in one or the other direction (WU and ROE 2005). Breeder welfare is generally higher under fixed performance standards, but the welfare advantage decreases with the relative size of a common shock (e.g., outbreaks of disease). Speculating about contractual approach, I think that efforts to implement tournament contracts in a Scandinavian context will prove to be difficult based on the traditions with a cooperative system in the agribusiness. In a Brazilian context though, it might be easier, as the units (chicken breeders) are smaller and also less resourceful.

\section{Conclusions}

The question we wanted to explore in this article was how different companies in the same industry have chosen to approach competition in regard to governance structure and contractual design, broadly seen as their competitive mode. What we have seen is two very different ways of organizing production, even though both companies are concerned with the cost of production. One company is very close to what is described as the benchmark of the poultry industry, an integrated structure, and one is seemingly very distant from the benchmark. Both companies though are doing well. What we have not dealt with is why these differences appear in an industry with the same kind of worries like margin control, biosecurity, quality, and challenges related to avoiding production disruptions. We have touched upon it, in regard to differences in domestic competition and also possible differences in traditions in the agribusiness industry in the two countries. There might be other reasons why companies choose different competitive modes, e.g. different agricultural policy, judicial maneuverability, etc. These are tough questions that need to be further explored.

\section{References}

ANDERSEN, R.K., S.Skinnarland and R. Tveterås. 'Fra bonde til butikk: En studie av verdikjeder i kjøttbransjen', Fafo-rapport, 19, 2008.

Brazilian Poultry Association: Annual report. <http://www.brazilianchicken.com.br/home/publicacoes>, 2012.

BROUSSEAU, E. and J-M. GLACHANT. 'The economics of contracts and the renewal of economics', in IE. Brousseauand J-M. Glachant(eds) The Economics of Contracts: Theories and Application, Cambridge: Cambridge University Press, pp.3-42, 2002.

Informe Gepec, Toledo, v. 18, n. 2, p. 147-162, jul./dez. 2014 
DOUMA, S. and H. SCHREUDER. Economic Approaches to Organizations, 3rd ed., Harlow: Prentice Hall, 2002.

DUBOIS, P. and T. VUKINA. 'Optimal incentives under moral hazard and heterogeneous agents: Evidence from production contracts data', International Journal of Industrial Organizatio, 27, 489-500, 2009.

EISENHARDT, K. 'Agency theory: An assessment and review', Academy of Management Review, 14 (1), 57-74., 1989.

GILSON, R.J., C.F. Sabel, and R.E. Scott. 'Contracting for innovation: Vertical disintegration and interfirm collaboration', Columbia Law Review, 109 (3), 431502, 2009.

HENRY, R. and G. ROTHWELL. 'The world poultry industry', IFC Global agribusiness series, Washington D.C.: World Bank, 1995.

KNUDSEN, C., Økonomisk Metodologi (economic methodology), København: Jurist- og Økonomforbundets Forlag, 1997.

KLEIN, B., R.G. CRAWFORD and A.A. ALCHIAN. 'Vertical integration, appropriable rents, and the competitive contracting process', Journal of Law and Economics, 21, (2), 297-326, 1978.

LANGLOIS, R.N. 'Transaction-cost economics in real time. In Foss, N.J. (ed), 'Resources, firms and strategies', pp. 287-305. Oxford: Oxford University Press, 1997.

LAR. 'Relatorio e Balanco', 2012, http://www.lar.ind.br/v3/cooperativa.php., 2012.

LEEGOMONCHAI, P. and T. VukiNa. 'Dynamic incentives and agent discrimination in broiler production tournaments', Journal of Economics \& Management Strategy,14 (4), 849-877, 2005.

LEVY, A. and T. VUKINA. 'Optimal linear contracts with heterogeneous agents', European Review of Agricultural Economics, 29 (2), 205-217, 2002.

LEVY, A. and T. VUKINA. 'The league composition effect in tournaments with heterogeneous players: An empirical analysis of broiler contracts', Journal of Labor Economics, 22 (2), 353-378, 2004.

MAcDONALD, J., J. PERRY, M. AHEARN, D. BANKER,W. CHAMBERS, C. DIMITRI, N. KEY,K. NELSON and L. SOUTHARD. Contracts, markets, and prices: Organizing the production and use of agricultural commodities, United States Department of Agriculture (USDA), Agricultural Economic Report Number 837, 2004.

MAcDONALD, J.M. The economic organization of U.S. broiler production, USDA, Economic Information Bulletin, No. 38, 2008.

MARTINEZ, S. W. Vertical coordination of marketing systems: Lessons from the poultry, egg, and pork industries, USDA, Agricultural Economic Report No. 807, 2002. 
NUNES, F.G. 'What is behind Brazilian broiler industry competitiveness?', World Poultry, 20 (12), 26-28, 2004.

OLESEN, H. B. 'Organization of agricultural production: A contract theoretical approach', PhD-thesis - Papers from Department of Economics and Natural Resources at Royal Veterinary and Agricultural University, Denmark. (downloaded $29^{\text {th }}$ of October 2013), 2002.

PERRY, M.K. 'Vertical integration: Determinants and effects',in R. Schmalensee and R.D. Willig (eds), Handbook of Industrial Organization, 1, pp. 183-255, Amsterdam: North Holland, 1989.

PORTER, M.E. Competitive Strategy: Techinques for Analyzing Industries and Competitors, New York: Free Press, 1980.

ROBERTSEN, P.L. and R.N. LANGLOIS. 'Innovation, networks, and vertical integration', Research Policy 24, 543-562, 1995.

SILVA, C.L., A.C.L. NOGUEIRA and M.S.M. SAES. Coexistence of governance structures in the broiler chicken industry: a comparative analysis of two Brazilian States. Paper presented at the IAMA 2005 Annual World Symposium, 2526.June, Chicago, IL, USA, 2005.

TAUBE-NETTO, M. 'Integrated planning for poultry production at Saida', INTERFACES, 26 (1), 38-53, 1996.

TSOULOUHAS, T. 'Do tournaments solve two-sided moral hazard problems?' Journal of Economic Behavior \& Organization, 40, 275-294, 1999.

TSOULOUHAS, T. and T. VUKINA, 'Integrator contracts with many agents and bankruptcy', American Journal of Agricultural Economics, 81, 61-74, 1999.

VUKINA, T. (2001), 'Vertical integration and contracting in the U.S. poultry sector', Journal of Food Distribution Research, 32 (2), 29-38, 2001.

VUKINA, T. and P. LEEGOMONCHAI. 'Oligopsony power, asset specificity, and hold-up: Evidence from the broiler industry', American Journal of Agricultural Economics, 88, (3), 589-605, 2006.

VUKINA, T. and X. ZHENG. 'Structural estimation of rank-order tournament games with private information', American Journal of Agricultural Economics, 89, 651-664, 2007.

VUKINA, T. and X. ZHENG. 'Homogenous and heterogenous contestants in piece rate tournaments: Theory and empirical analysis', Journal of Business \& Economic Statistics, 29 (4), 506-517, 2011.

WILLIAMSON, O. E. 'The vertical integration of production: Market failure considerations', The American Economic Review, 61 (2), 112-123, 1971.

WILLIAMSON, O. E. 'Transaction-cost economics: The governance of contractual relations', Journal of Law and Economics, 22 (2), 233-261, 1979.

WILLIAMSON, O. E. The Economic Institutions of Capitalism, New York: The Free Press, 1985. 
WILLIAMSON, O. E. 'Strategizing, economizing, and economic organization', Strategic Management Journal, 12, 75-94, 1991.

WU, S. and B. ROE. 'Behavioral and welfare effects of tournaments and fixed performance contracts: Some experimental evidence', American Journal of Agricultural Economics, 87, (1), 130-146, 2005.

WU, S. 'Regulating agricultural contracts: What are the tradeoffs?', CHOICES: The Magazine of Food, Farm and Resource Issues, 18 (1), 19-22, 2003.

WU, S. Y. 'Contract theory and agricultural policy analysis: a discussion and survey of recent developments', The Australian Journal of Agricultural and Resource Economics, 50, 490-509, 2006.

ZHENG, X. and T. VUKINA. 'Efficiency gains from organizational innovation: Comparing ordinal and cardinal tournament games in broiler contracts', International Journal of Industrial Organization, 25, 843-859, 2007.

Sobre a autor

\section{Jan Ole Similä}

PhD, Associate professor, Nord-Trøndelag University College.

E-mail: jan.o.simila@hint.no 